\title{
Investors' Risk Preference and Age in Korean Defined Contribution Plans
}

\author{
Inwook Song, Director of the Center, Korea Fund Ratings Co. \\ Kyonghee Lee $^{* *}$, Professor, Sangmyung University
}

\begin{abstract}
$\langle$ Abstract $\rangle$
Our study investigates the relationship between investors' age and investment risk preference. We use a unique dataset-defined contribution plan account data (observations $=18,781$ ), provided by a Korean financial institute (a recording-keeping service provider). Investment risk preference is measured by three variables: share of equity, five-year volatility of selected funds, and share of principal guaranteed products. While controlling for individual characteristics such as gender, employee status, plan duration, wage, accumulated assets, and number of employees, we test the relationship between individuals' age and investment risk preference in asset allocation. Echoing the results of previous studies, we find that age is significantly related to investment risk preference. Both equity share and volatility have an inverted-U-shaped relationship with age, and the share of principal guaranteed products has a U-shaped curve coinciding with age. Our results indicate that age is associated with increased risk preference due to learning effects and greater financial understanding. However, after reaching a certain point, risk preference decreases because of the need for a secure retirement income. Finally, the estimated coefficients of the interaction effect variables show that some individual groups - executives, high earners, and large asset holders - are more risk-taking than are other same-age groups.
\end{abstract}

Keywords: Retirement Pension Fund; Pension Service Provider; Defined Contribution Participants; Investment Risk Preference; Age

JEL Classification: G10, G20

\footnotetext{
* This research was supported by New Scholars Grant Program from the Korean Securities Association and Mirae Asset in 2018.

** Corresponding Author. Address: Sangmyung University, 31, Sangmyeongdae-gil, Dongnam-gu, Cheonan-si, Chungcheongnam-do, Korea 31066; E-mail: khlee@smu.ac.kr; Tel: +82-41-550-5442; Fax: +82-41-550-5316.
}

Received: March 7, 2019; Revised: May 14, 2019; Accepted: June 3, 2019 


\title{
확정기여형 퇴직연금 가입자의 연령이 위험선호에 미치는 영향*
}

송 인 욱 (한국펀드평가 리서치센터장)

이 경 희 (상명대학교 교수)**

\begin{abstract}
본 연구에서는 확정기여형 퇴직연금 가입자의 연령이 위험자산 선택에 유의한 영향을 미치는지 검증하였다. 분석을 위해 퇴직연금사업자가 제공한 개인별 기록관리 데이터 1 만 8 천여 개를 활용하였다. 가입자의 위험선호도는 적립금의 주식 투자 비중, 선택한 펀드의 5 년 평균 변동성, 원리금보장상품 비중으로 측정하였다. 개인별 특성(성별, 임원, 가입기간, 급여, 적립금 등)을 통제한 상태에서 연령과 위험선호도 사이의 관계에 대해 3 개의 회귀모형을 추정하였다. 변동성과 주식투자 비중에 대한 모형을 각각 추정한 결과, 연령의 회귀계수는 양(+), 연령제곱의 회귀계수는 음(-)으로 추정되었다. 이는 위로 볼록한 비선형관계의 존재를 시사한다. 원리금보장상품 비중에 대한 모형에서도 연령 변수는 음 $(-)$, 연령제곱 변수는 양 $(+)$ 으로 추정되어 아래로 볼록한 비선형함수가 확인되었다. 이러한 결과는 연령이 증가함에 따라 학습효과와 금융이해력이 높아지면서 위험선호도도 높아지지만, 일정 수준에 도달한 이후에는 안정적인 은퇴자금을 확보하려는 니즈가 높아져 위험선호도가 낮아지기 때문으로 풀이된다. 아울러, 연령과 종사상 지위, 급여, 적립금 수준 사이의 상호작용 효과를 검증한 결과, 동일한 연령대에서 임원일수록, 임금 소득이 많을수록, 그리고 적립금 규모가 클수록 위험선호도도 높아지는 것으로 나타났다.
\end{abstract}

핵심 단어 : 퇴직연금펀드, 퇴직연금사업자, 확정기여형 투자, 연령, 위험선호도

JEL 분류기호: G10, G20

* 본 연구는 2018년 한국증권학회-미래에셋자산운용 신진학자 연구지원사업의 연구지원을 받아 수행되었습니다.

** 연락담당 저자. 주소: 충청남도 천안시 동남구 상명대길 31 상명대학교 글로벌금융경영학과, 31066; E-mail: khlee@smu.ac.kr; Tel: 041-550-5442; Fax: 041-550-5316. 


\section{1. 서론}

\section{1 문제제기}

2005년 12월 다층노후소득보장체계 구축을 위해 우리나라에 퇴직연금제도가 도입된 지 벌써 12 년이 지났다. 우리나라 퇴직연금제도는 법정 퇴직금제도에서 이행하였기 때문에 제도의 유형 및 운영방식이 자생적으로 퇴직연금제도가 발달한 선진국과는 상당히 다른 것이 사실이다. 그럼에도 불구하고, 도입 이후 임금상승, 근속연수 증대, 투자수익 등의 영향으로 적립금 규모는 빠른 속도로 증가하였고, 향후 선진국과 마찬가지로 가계의 금융자산에서 퇴직연금 적립금이 차지하는 비중도 높아질 것이다.

2017년 상반기 기준 전체 퇴직연금 가입자 중 45\% 정도가 확정기여형제도(DC: Defined Contribution)에 소속되어 있다(Statistics Korea, 2018).1) 확정기여형은 사용자(고용주)가 최소한 매년 근로자 임금의 $1 / 12$ 이상 부담금을 납부하면 법적 책임을 다하는 제도이다. 가입자 본인(근로자)이 적립금을 운용하고 투자위험도 부담하게 되며 그 운용결과에 따라 적립금 규모가 결정된다. 투자에 대한 위험을 사용자가 부담하는 확정급여형제도(DB: Defined Benefit)는 주로 대기업, 고임금, 남성 중심으로 도입된 반면, 확정기여형은 이직이 잦은 직종, 연봉제 사업장, 계약직 중심으로 도입되었다. 향후 산업구조 변화, 임금피크제 활용 등 노동시장 유연화 환경을 고려할 때 확정기여형 가입자의 비중은 지속적으로 증가할 것이다. 따라서 이들이 어떻게 자산을 배분하는가에 정보는 퇴직연금제도를 둘러싼 이해관계자에게 매우 중요한 정보가 된다. 그러나 국내 확정기여형 가입자의 위험자산 투자에 대한 연구는 많지 않다. 다양한 사업장에 종사하는 개인들을 대상으로 한 연구가 미진한 것은 개인별 미시데이터를 입수하기 어렵기 때문이다.

본 연구에서는 확정기여형 퇴직연금 가입자의 계좌정보를 대상으로 다양한 개인별 특성변수를 통제한 상태에서 연령과 위험선호 사이의 관계를 검증하고자 한다. 개인의 자산배분에 대한 의사결정에서 연령은 위험회피도의 변화를 초래하는 요인이 된다. 젊은 연령에서는 소득이 적고, 축적된 자산이 거의 없기 때문에 위험회피도가 높은 반면, 중장년층에서는 소득이 높아지고, 축적된 자산도 증가하기 때문에 위험회피도가 낮아진다. 생애 후반인 은퇴시기가 다가오면 손실회복을 위한 기간이나 자산이 감소하게 되어 다시 위험회피도가 높아진다. 이 내용을 기초로 하여 연령과 위험선호 간 관계를 나타내면 위로 볼록한 비선형함수를 예상할 수 있다. 즉, 젊은 시기에는 유동성 니즈가 높고, 소비를 유지하기 위해 차입을 하기 때문에 저위험 포트폴리오가 바람직한 반면, 연령이 높아짐에 따라 점차 위험자산의 비중을 늘린 후 은퇴에 임박하면 위험자산 비중을 축소하는 것이 바람직하다. 따라서 이 가설에 의하면 연령과 위험자산 보유 사이에는 위로 볼록한 관계(역U자)를 갖게 된다.

1) 2017년 6월 말 기준 퇴직연금제도 유형별 가입 근로자 수 비중은 확정급여형(DB: Defined Benefit) $55.1 \%$, 확정기여형 $42.1 \%$, 개인형 퇴직연금제도(IRP: Individual Retirement Pension) $1.2 \%, \mathrm{DB}$ 와 $\mathrm{DC}$ 병행 $1.6 \%$ 임. 확정기여형 가입 비중을 성별로 보면, 여성(61.4\%)이 남성 $(38.6 \%)$ 보다 $22.8 \% \mathrm{p}$ 나 높음. 
Investors' Risk Preference and Age in Korean Defined Contribution Plans

본 연구는 국내 확정기여형 퇴직연금 가입자의 연령과 위험선호 사이의 관계를 분석하였다는 점에서 선행연구와 차별화된다. 또한, 선행연구(Kim and Lee, 2013)에 비해 분석대상을 크게 확대하였다는데 기여가 있다. 확정기여형제도를 운영하고 있는 350 여개 사업체를 대상으로 1 만 8천여명의 가입자를 표본으로 추출하였다. 2017년 상반기 기준으로 이들이 선택한 펀드의 5 년 변동성, 펀드 내 주식투자비중, 원리금보장상품비중을 위험선호도의 대리변수로 사용하였다. 본 연구의 결과는 선행연구에 비해 전체 가입자 집단으로 일반화시킬 수 있어 확정기여형 가입자, 퇴직연금사업자, 상품제공기관, 감독 및 정책당국에 유용한 정보를 제공할 것이다.

\section{2 선행연구}

개인의 연령과 위험자산 투자에 대한 실증분석은 일반펀드 가입자와 퇴직연금 가입자를 대상으로 이루어졌으며 다수의 실증연구에서는 연령과 주식투자 비중 양(+)의 관계(Bailey et al., 2011)가 존재하지만, 연령 증가에 따라 다시 감소하는 관계가 나타났다(Choi, 2013; Agnew et al., 2003; Ameriks and Zeldes, 2004; Bajtelsmit and VanDerhei, 1997).

퇴직연금 가입자를 대상으로 한 연구는 확정기여형 가입자의 투자 경험이 풍부한 미국 중심으로 이루어졌다. Agnew et al.(2003)는 401(k)제도를 운영하는 1개 사업장 가입자를 대상으로 패널데이터를 구축한 후 개인별특성이 자산배분에 미치는 영향을 분석하였다. 분석결과, 주식투자 비중은 남성, 기혼자, 고소득자 및 안정적인 직무 종사자 집단에서 높은 것으로 나타났고, 연령과 주식비중 사이에는 역U자형 관계가 존재하였다. Ameriks and Zeldes(2004)는 연방준비은행의 서베이 자료(Surveys of Consumer Finances)와 교직원퇴직연금(TIAA-CREF)의 패널자료를 활용하여 연령과 포트폴리오 선택 간 관계를 분석하였다. 분석 결과, 연령이 증가함에 따라 주식투자 비중이 감소하는 현상은 명확하게 드러나지 않았다. 연구진은 22 55세의 주식보유 비중은 연령 중립적이며, 56 70세에서는 연령과 음(-)의 관계에 있다고 보았다. 이는 퇴직연금 가입자가 은퇴시점에 도달하여 퇴직연금 적립금을 연금전환(annuitizations)하거나 인출(withdrawals)하는 연령대에서 주식투자를 축소하는 것으로 해석된다.

이에 비해 Cardak and Wilkins(2009)는 호주 가계를 대상으로 위험자산 보유에 영향을 주는 요인을 분석하였는데, 은퇴직전 위험자산을 축소한다는 예상과 달리 55 59세, 60 64세, 65 69세 계층에서 위험자산을 더 많이 보유하는 것으로 나타났다. 이런 결과는 연령대가 높아짐에 따라 투자기회와 투자지식도 증가하기 때문으로 보인다. 한편, Lusardi and Mitchell(2011)은 연령과 금융지식 사이의 관계를 국가별로 비교하였다. 8개국(독일, 네덜란드, 스웨덴, 일본, 이태리, 뉴질랜드, 미국, 러시아)을 대상으로 분석한 결과, 젊은 계층과 노인 그룹의 금융지식이 가장 낮고, 중년 그룹이 가장 높은 것으로 나타났다. 금융지식이 많은 사람이 은퇴준비를 더 잘할 수 있기 때문에 연령변수가 은퇴준비에도 영향을 미치는 것으로 볼 수 있다.

Bailey et al.(2011)은 미국의 대형 증권회사가 보유한 일반펀드 투자자를 대상으로 펀드 선택행동을 분석하였다. 투자자 개인별 특성변수(연령, 결혼여부, 가계구성원 수, 직종 및 은퇴여부 등)에 대한 회귀분석 결과 연령과 인덱스펀드 투자 간 유의한 정(+)의 관계가 나타났다. 
한국증권학회지 제48권 6호 (2019)

연령이 위험자산선택에 미치는 영향에 대한 국내 연구로는 Choi(2013), Song et al.(2014), Kim and Lee(2013) 등이 있다. Choi(2013)은 가계금융조사 자료를 이용하여 사회통계인구학적 요인과 자산배분행동간 관계를 분석하였다. 연령계층을 6 개 그룹으로 구분하여 위험금융자산 비율을 비교한 결과 30 대부터 50대에 이르기까지의 비율이 다른 연령대에 비해 더 높은 것으로 나타났다. Song et al.(2014)은 주식형펀드 계좌 데이터를 이용하여 펀드투자자의 연령과 투자성과 사이의 관계를 검증하였다. 연령과 투자성과 간에는 양 $(+)$ 의 관계가 존재하며 이 관계는 거치식 계좌보다 적립식계좌에서 더 크다는 것을 발견하였다. 위험자산의 프리미엄을 고려한다면 연령과 위험자산 보유 간에도 양 $(+)$ 의 관계가 존재한다고 추론할 수 있다.

Kim and Lee(2013)는 국내 확정기여형 퇴직연금제도 가입자를 대상으로 자산배분행동을 분석하였다. 기술통계에서는 연령계층과 주식투자 비중 간 비선형(역U자형) 관계가 나타났으나, 회귀분석 결과에서는 통계적으로 유의한 관계가 드러나지 않았다. 대상 사업체가 1 개로 국한되고 가입이력(2008 2012년)이 일천하며 원리금보장형 중심으로 선택하였기 때문에 연령과 위험 자산 투자간 통계적 유의성이 낮게 나타난 것으로 보인다.

\section{3 연구 구성}

본 연구의 구성은 다음과 같다. 제 1 장 서론에 이어 제 2 장에서는 연구에 사용된 데이터, 주요 통제변수 및 분석방법에 대해 설명한다. 제 3 장에서는 퇴직연금 가입자를 5 개 연령그룹별로 구분하여 위험선호도 차이를 살펴보고, 연령과 위험선호 사이의 관계에 대해 회귀분석을 실시한다. 아울러 연령과 종사상 지위, 급여, 적립금 수준 간 상호작용효과에 대해서도 검증한다. 제 4장 에서는 연구결과를 요약하고 이에 대한 의의를 논의하면서 끝을 맺는다.

\section{2. 연구자료 및 분석방법}

\section{1 연구방법론}

퇴직연금 가입자의 연령이 위험선호도에 미치는 영향을 분석하기 위한 방법으로는 이와 유사한 연구인 Song et al.(2014) 방법을 이용한다. 단, Song et al.(2014)는 공모펀드 투자의 결과물인 계좌수익률에 초점을 맞추어 분석을 했다면, 본 연구에서는 퇴직연금 가입자의 위험선호도와 연령 간의 관계에 초점을 맞추어 분석한다.

먼저, 퇴직연금 가입자의 위험선호도에 대한 정의가 필요하다. 이는 가입자가 설정한 자산군별 배분비중을 통해 도출한다. 퇴직연금 가입 시 가입자는 원리금보장상품과 실적배당상품 간의 배분을 수행하여야 하며, 실적배당상품은 판매사별로 차이가 있으나 대략 주식형, 주식혼합형, 채권혼합형, 채권형, 현금성 등 5 개 유형으로 분류가 가능하다. 원리금보장상품을 포함한 총 6 개 유형에 대한 배분비중을 통하여 가입자의 위험선호도를 계산한다. 먼저, 변동성의 경우, 퇴직연금 가입자의 상품유형별 배분비중에 상품유형별 변동성을 가중평균 하여 계산한다. 이때의 
Investors' Risk Preference and Age in Korean Defined Contribution Plans

상품유형별 변동성은 2017년도 말 동일유형 공모펀드2)의 최근 5년간 월별수익률 표준편차를 연환산한 값이다. 다음으로 주식비중의 경우 또한 퇴직연금 가입자의 상품유형별 배분비중에 상품유형별 주식비중을 가중평균 하여 계산한다. 이때의 주식비중은 동일유형 공모펀드의 평균 주식비중을 적용한다. 상품유형별 변동성과 주식비중은 <표 1>에 제시하였다.

\section{〈표 1〉상품유형별 주식비중 및 변동성}

이 표는 퇴직연금 상품유형별 주식비중과 변동성 대용치를 보여주고 있다. 주식비중은 동일유형 공모펀드의 각 유형별 평균 주식비중이며, 변동성은 2017 년도 말 최근 5년간의 월별수익률의 변동성을 연환산 한 값이다.

\begin{tabular}{lcccccc}
\hline & 원리금 & \multicolumn{5}{c}{ 실적배당상품 } \\
\cline { 3 - 6 } & 보장상품 & 주식형 & 주식혼합형 & 채권혼합형 & 채권형 & 현금성 \\
\hline 주식비중 & $0 \%$ & $87 \%$ & $65 \%$ & $30 \%$ & $0 \%$ & $0 \%$ \\
변동성 & $0 \%$ & $8.1 \%$ & $4.3 \%$ & $2.3 \%$ & $1.0 \%$ & $0 \%$ \\
\hline
\end{tabular}

앞에서 가입자의 위험선호도 변수를 정의하였고, 다음으로 위험선호도에 영향을 미칠 것으로 판단되는 변수들을 통제한 상태에서 위험선호도와 가입자 연령 사이의 관계를 분석하기 위하여 아래와 같은 횡단면회귀모형을 설정한다.

$$
\text { 위험선호도 }{ }_{i}=f\left(\text { 가입자의 연령 }_{i}, \text { 통제변수 }_{i}\right)+\epsilon_{i}
$$

여기에서 위험선호도는 앞에서 계산된 가입자 $i$ 의 변동성, 주식비중, 원리금보장상품비중을 의미한다. 모형에서 연령이 높아질수록 위험선호도가 크다면 변동성과 주식비중과는 회귀계수가 양(+)의 값, 원리금보장상품비중과는 음(-)의 값을 보일 것이다. 선행연구들에서는 학습효과로 인해 연령이 높아질수록 투자자의 수익률이 높아진다고 나타났으며, 투자성과는 위험부담(risktaking)의 결과물이라고 본다면 위험선호도 또한 증가할 것으로 기대된다.

통제변수로는 성별, 임원, 가입기간, 급여, 누적적립금, 추가납입, 중도인출, 사업체 종사자 수를 사용한다. 먼저 성별은 남성의 경우 1 의 값을 부여하고 여성의 경우 0 의 값을 부여하는 이항변수(binary variable)이다. Lusardi and Michell(2011)은 남성이 여성에 비해 금융이해력 (financial literacy)이 상대적으로 높은 것으로 보고하였으며, Bailey et al.(2011)에 따르면 남성이 여성에 비해 과거성과가 높은 펀드에 주로 투자하는 경향이 있다고 밝혔다. Barber and Odean(2001)은 남성이 과도한 자신감으로 여성에 비해 주식거래를 많이 하나 그 결과 순이득은 감소한다고 밝혔다. 국내연구인 Joung and Shin(2011), Lee and Jung(2011), Choi(2013) 등에 따르면 여성에 비해 남성이 위험수용성향이 높아 위험자산보유율이 높다고 보고하였다. 따라서 본 연구의 회귀모형에서는 성별더미와 위험선호도 사이에 양(+)의 관계가 존재할 것으로 기대된다. 다음으로 임원 또한 임원의 경우 1 의 값을 부여하고 근로자(일반직원)의 경우 0의 값을 부여하는 이항변수이다. 종사형태에 따른 투자성과나 위험선호를 분석한 선행

2) 공모펀드 자료 및 유형분류 기준은 한국펀드평가(주)의 자료를 사용하였다. 한국펀드평가의 유형분류 및 평가방법론은 해당사의 홈페이지에서 조회가 가능하다(http://www.kfr.co.kr/fnd/fnd400000). 
한국증권학회지 제48권 6호 (2019)

연구는 없으나, 상대적으로 높은 급여를 받고, 금융이해력이 높을 것으로 예상되는 임원이 위험 선호도가 높을 것으로 기대된다.

급여와 누적적립금은 가입자의 소득수준과 자산수준을 대용하는 변수라고 볼 수 있다. Niebling et al.(2009)에 따르면 부유층일수록 펀드의 과거성과를 보다 적극적으로 고려하여 펀드를 선택하는 경향이 있으며, Tang et al.(2010) 또한 소득이 높을수록 보다 우수한 의사결정을 내린다고 밝혔다. 소득수준과 연관된 연구는 아니지만 Choi(2013)은 교육수준이 높을수록 위험선호도가 높아진다고 밝혔다. 일반적으로 투자규모가 클수록 투자정보 획득에 보다 많은 노력을 기울일 것이고, 소득수준이 높을수록 교육수준 또한 높다는 점을 고려한다면, 소득수준을 나타내는 급여와 적립금 모두 위험선호도와 양(+)의 관계를 보일 것으로 기대된다.

추가납입은 사용자의 법정부담금 외에 추가적으로 가입자 본인이 기여금(부담금)을 납입하는 경우이다. 세액공제의 목적으로 세액공제 한도 내로 추가 납입하는 것이 일반적이다. 즉, 추가 납입을 하는 가입자는 세액공제 제도에 대한 이해도가 있으며, 노후준비를 위해 장기상품인 퇴직연금에 납입이 가능할 정도로 일정규모 이상의 자산을 보유하고 있다는 의미로 해석이 가능하다. 즉, 금융이해력이나 소득수준 측면에서 봤을 때, 위험선호도와 양 $(+)$ 의 관계를 보일 것으로 기대된다. 반면, 중도인출은 주택구입, 장기요양, 파산 등 목돈이 필요한 경우이다. 즉, 퇴직연금을 제외한 자산이 부족함을 의미하며, 현재 삶을 위해 일정부분 노후소득을 포기한 것이다. 이는 추가납입과 상반되는 것으로 위험선호도와 음(-)의 관계를 보일 것으로 예상된다. 마지막으로 사업장의 종사자 수는 사업장 규모의 대용치이다. 사업장이 영세한 경우, 퇴직연금에 대한 이해도가 낮을 뿐만 아니라, 종사자 대부분도 금융지식이 낮을 것으로 예상된다. 반면, 대형 사업장의 경우, 근로자의 권익을 위한 단체(예: 노동조합)가 존재하며, 법정의무교육뿐만 아니라 다양한 교육활동 및 지원활동이 이루어진다. 즉, 상대적으로 대형사업장이 투자에 대한 정보수집, 금융이해력, 근로자의 교육수준 측면에서 영세사업장보다 우위에 있을 것으로 예상된다. 이에 종사자 수와 위험선호도는 양 $(+)$ 의 관계를 보일 것으로 기대된다. 급여와 누적적립금, 추가납입, 중도인출은 로그정규분포의 특성을 가지고 있어 자연로그를 취한 값을 사용한다.

\section{2 연구자료}

본 연구에서 사용된 자료는 2017년 상반기 기준 특정 퇴직연금사업자가 보유한 확정기여형 가입자의 계좌정보이다. 계좌별로는 가입자특성인 연령, 성별, 종사형태, 급여수준, 적립금규모가 식별가능하며, 퇴직연금 상품의 유형별 배분비중과 원리금보장상품의 비중 정보를 포함하고 있다.

<표 2>는 분석대상으로 선택된 18,781 개 계좌를 퇴직연금 가입자의 연령(10세 간격)을 기준으로 분류하고, 각 그룹의 성별과 종사형태별 계좌 수와 그룹별 급여 및 적립금 수준을 제시하고 있다. 퇴직연금의 경우, 가입기간 중 자산배분이 자유롭기 때문에 주요 변수인 연령은 자료수집 시점을 기준으로 사용한다. 먼저, 가입자 수는 사회활동이 가장 활발한 30 대와 40 대에 가장 많고, 본격적인 퇴직준비를 수행하는 50세 이후로는 감소하는 추세를 보인다. 이러한 추세는 
Investors' Risk Preference and Age in Korean Defined Contribution Plans

성별계좌에서도 동일하게 나타난다. 하지만 상대적으로 남성의 경우 50 대 이상 그룹에서도 가입자가 높게 유지되는 반면, 여성은 40대부터 표본수가 급격히 감소하는 추세를 보인다. 이는 결혼 이후 육아문제로 인해 사회활동에 제약이 발생하는 현상을 반영한 수치로 보인다. 종사형태 별로는 근로자의 경우, 전체 표본과 동일하게 30 대와 40대에 높은 비중을 보이지만, 임원의 경우 50 대가 가장 높은 비중을 차지한다. 급여수준과 누적적립금을 보면, 연령이 증가할수록 높아지는 추세를 보인다. 이는 근무연차가 증가함에 따라 급여가 증가하는 자연스러운 결과라 하겠다. 다만, 60 대에서는 급여나 누적적립금이 감소하는데, 이는 정년연장을 위한 임금피크제 선택, 정년퇴직 후 재취업 등에 기인한 것으로 보인다.

\section{〈표 2〉연령그룹별 표본분포}

이 표는 분석에 사용된 퇴직연금 가입자 18,781 개 계좌 데이터의 분포를 보여주고 있다. 연령에 따라 5 개 간격으로 분류하여 각 그룹의 성별 계좌수, 종사형태별 계좌수, 평균 급여 및 적립금 규모를 보여주고 있다.

\begin{tabular}{|c|c|c|c|c|c|c|c|}
\hline \multirow{2}{*}{ 절 대그룹 } & \multirow{2}{*}{ 표본수 } & \multicolumn{2}{|c|}{ 성별 } & \multicolumn{2}{|c|}{ 종사형태 } & \multicolumn{2}{|c|}{ 급여수준 (천 원) } \\
\hline & & 남성 & 여성 & 근로자 & 임원 & 급여 & 적립금 \\
\hline 29세 이하 & 2,008 & 916 & 1,092 & 2,008 & 0 & 4,180 & 9,255 \\
\hline 30 39세 & 6,776 & 4,692 & 2,084 & 6,772 & 4 & 5,801 & 24,655 \\
\hline 40 49세 & 6,198 & 5,111 & 1,087 & 6,108 & 90 & 7,536 & 53,614 \\
\hline 50 59세 & 3,628 & 3,282 & 346 & 3,502 & 126 & 8,437 & 88,061 \\
\hline 60세 이상 & 171 & 147 & 24 & 149 & 22 & 5,802 & 58,598 \\
\hline 전체 & 18,781 & 14,148 & 4,633 & 18,539 & 242 & 6,709 & 45,123 \\
\hline
\end{tabular}

<표 3>는 본 연구의 분석에 사용된 변수들의 기초통계량을 보여주고 있다. 우선, 변동성의 평균과 중위수는 각각 $1.48 \%$ 와 $1.44 \%$ 로 낮은 수준을 보이고 있다. 이는 공모펀드 기준으로 채권형보다 소폭 높은 수준으로 표본의 평균적인 퇴직연금 가입자는 채권형 수준으로 퇴직연금을 운용하는 것으로 보인다. 주식비중 또한 평균이 $16.24 \%$ 로 평균적인 채권혼합형 내 주식비중 $30 \%$ 수준)의 절반에 불과하다. 반면 원리금보장상품비중은 평균이 $37.92 \%$ 로 전체 자산의 $40 \%$ 수준을 원리금보장상품으로 운용한다. 실적배당형 내 현금성자산까지 포함한다면 전체자산의 절반 이상을 원금이 보장되는 상품으로 운용하는 것이다. 이상 퇴직연금 가입자의 위험선호지표를 보면, 국내 퇴직연금 가입자들은 퇴직연금에 대해 매우 보수적으로 자산운용을 하고 있다고 하겠다. 한편 <표 $3>$ 하단부터는 본 연구의 주요설명변수인 연령과 통제변수들에 대하여 제시하였다.

퇴직연금 가입자 연령의 경우, 가장 왕성한 사회활동을 하는 40 대 초반(41.58세)이 평균으로 나타났다. 성별더미와 임원더미의 평균은 각각 0.75 와 0.01 로 전체 표본의 약 $75 \%$ 가 남성이며, $99 \%$ 는 근로자이다. 퇴직연금 제도가 2005년 12 월에 도입되었기 때문에 가입기간의 평균과 중위수는 각각 4.97년과 4.58년으로 채 5년이 않는다. 급여와 누적적립금의 평균은 각각 6,709 천 원과 45,123 천 원이다. 누적적립금의 경우 약 1 백만 원에서부터 약 11 억 원까지 분포하고 있으며, 
한국증권학회지 제48권 6호 (2019)

전체 표본 중 평균값은 45 백만 원 수준이다. 세액공제 등의 목적으로 추가 납입한 표본 수는 681 건으로 전체 표본의 $4 \%$ 수준에 불과하다. 그 금액은 세액공제 한도의 절반 수준인 336만 원이며, 중위수는 300 만 원이다.3) 퇴직연금을 추가 납입할 수 있는 가입자는 상대적으로 생활수준이 높고 노후준비에 대한 관심이 높은 사람으로 예상된다. 해당 가입자는 개인연금을 납입할 것이고, 이에 추가납입 중위수가 300 만 원으로 나타난 것으로 보인다. 반면, 중도인출은 추가납입의 두 배에 가까운 1,197 건에 이른다. 중도인출은 주택구입, 주택임차, 장기요양, 파산 등 목돈이 필요할 때 행해지기 때문에, 중도인출 금액은 누적적립금 수준에 육박한다. 평균 중도인출 금액은 46,402천 원이며, 중위수는 32,116 천 원이다. 마지막으로 사업장 규모의 대용변수인 종사자 수는 최소 3 명부터 38,000 명에 이르는 분포를 보인다. 중위수가 500 명으로 시장 전체 대비 표본 내 대형사업장의 비중이 높게 포함되어 있다. 이는 개별 금융기관의 계좌정보를 사용하기 때문에 발생한 한계로 향후 중·소규모 사업장의 퇴직연금 정보가 확보된다면 추가적인 연구가 필요하다고 하겠다.4)

\section{〈표 3〉기초통계량}

이 표는 분석에 사용된 변수의 기초통계량을 보여주고 있다. 종속변수인 위험선호지표는 변동성, 주식비중, 원리금보장상품의 비중이다. 변동성은 각 계좌의 펀드유형별 자산배분 비중에 동일유형의 과거 5 년간 공모펀드의 표준편차를 곱하여 계산하였으며, 주식비중은 펀드유형별 자산배분 비중에 유형별 평균 주식투자비중을 곱하여 계산한다. 펀드유형은 주식형, 주식혼합형, 채권혼합형, 채권형, 현금성의 5 개 자산군이며, 각 유형의 주식비중은 주식형의 경우, $87 \%$, 주식혼합형은 $65 \%$, 채권형은 $30 \%$, 현금성은 $0 \%$ 로 가정한다. 본 연구의 주요 설명변수로서 가입자의 연령을 사용한다. 그리고 통제변수로는 성별더미 (남성 $=1$, 여성 $=0$ ), 임원더미 (근로자 $=0$, 임원 $=1$ ), 가입기간(연), 급여(천 원), 누적적립금(천 원), 추가납입(천 원), 중도인출(천 원), 사업장의 종사자 수이다.

\begin{tabular}{|c|c|c|c|c|c|c|c|}
\hline 변수 & 변수 & 표본수 & 평균 & 중위수 & 표준편차 & 최솟값 & 최댓값 \\
\hline \multirow{3}{*}{$\begin{array}{l}\text { 종속 } \\
\text { 변수 }\end{array}$} & 변동성(\%) & 18,781 & 1.48 & 1.44 & 1.40 & 0.00 & 6.52 \\
\hline & 주식비중(\%) & 18,781 & 16.24 & 15.19 & 15.77 & 0.00 & 69.99 \\
\hline & 원리금보장비중(\%) & 18,781 & 37.92 & 9.38 & 42.20 & 0.00 & 100.00 \\
\hline \multirow{9}{*}{$\begin{array}{l}\text { 통제 } \\
\text { 변수 }\end{array}$} & 연령 & 18,781 & 41.58 & 41.01 & 9.16 & 19.23 & 64.83 \\
\hline & 성별더미(남성 = 1 , 여성 =0) & 18,781 & 0.75 & 1.00 & 0.43 & 0.00 & 1.00 \\
\hline & 임원더미 $($ 근로자 $=0$, 임원 $=1)$ & 18,781 & 0.01 & 0.00 & 0.11 & 0.00 & 1.00 \\
\hline & 가입기간(연) & 18,781 & 4.97 & 4.58 & 3.11 & 0.01 & 11.50 \\
\hline & 급여(천 원) & 18,781 & 6,709 & 5,449 & 4,628 & 1,574 & 30,000 \\
\hline & 누적적립금(천 원) & 18,781 & 45,123 & 28,104 & 51,658 & 1,001 & $1,126,190$ \\
\hline & 추가납입(천 원) & 681 & 3,359 & 3,000 & 2,559 & 100 & 18,100 \\
\hline & 중도인출(천 원) & 1,197 & 46,402 & 32,116 & 60,632 & 2,037 & $1,444,739$ \\
\hline & 사업장의 종사자 수 & 18,781 & 2,476 & 500 & 5,221 & 3 & 38,000 \\
\hline
\end{tabular}

3) 세법상 연금계좌(연금저축+퇴직연금)에 대한 세액공제 총 한도는 700 만 원이며, 유형별로 보면, 연금저축 400 만 원, 퇴직연금 700 만 원임. 따라서 퇴직연금 가입자가 연금저축 세액공제 한도(400만 원)를 충족하였다면, 퇴직연금 세액공제 한도는 300만 원이 됨.

4) 통계청에 따르면 2016년 기준 전체 종사자 수는 $21,259,243$ 명이며, 이 중 500 인 이상 사업장에 종사하는 근로자 수는 $2,274,228$ 명으로 전체의 $11 \%$ 를 차지한다. 
Investors' Risk Preference and Age in Korean Defined Contribution Plans

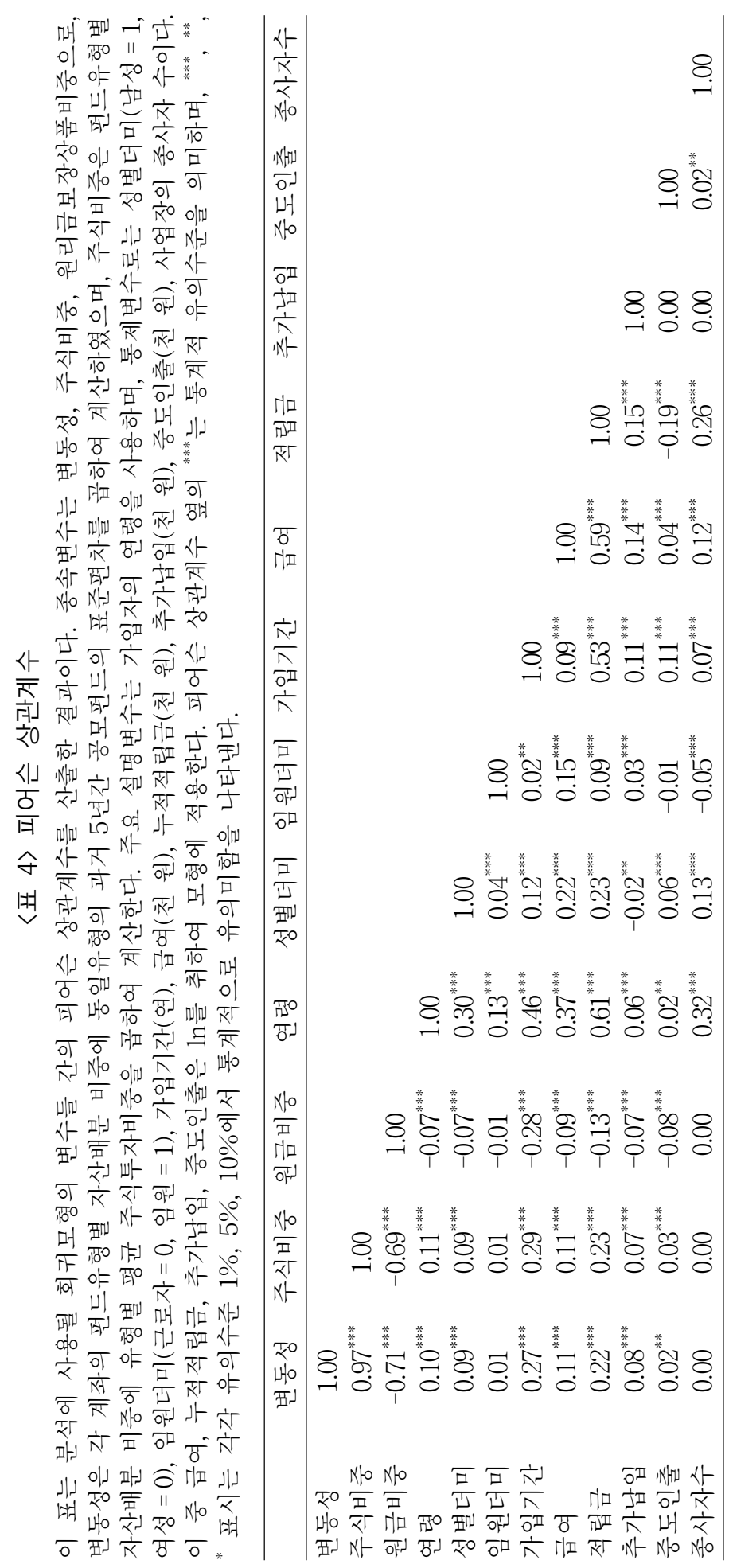


한국증권학회지 제48권 6호 (2019)

한편 <표 4>는 회귀분석에 포함되는 종속변수와 설명변수들 사이의 피어슨 상관계수를 산출한 결과이다. 대다수의 설명변수와 종속변수 사이에 통계적으로 유의한 관계가 존재하며, 방향성도 사전에 예측한 바와 큰 차이를 보이지 않는다. 임원더미를 제외하면 각 설명변수가 위험선호도와 유의미한 상관관계를 보인다. 변동성과 주식비중과는 양 $(+)$ 의 상관관계를 보이는 반면, 원리금보장상품비중과는 음(-)의 상관관계를 보인다. 그러나 이는 단변량분석이기 때문에 다양한 가입자특성을 고려하고도 연령과 위험선호도 간에 유의미한 양(+)의 관계가 존재하는지 분석할 필요가 있다.

\section{3. 실증분석}

\section{1 퇴직연금 가입자의 연령과 위험선호도}

\subsection{1 연령그룹별 위험선호도}

<표 5>는 퇴직연금 가입자의 연령그룹별 위험선호도를 산출한 것이다. 위험선호도는 가입자의 상품유형별 배분비중을 사용하여 변동성, 주식비중, 원리금보장상품비중으로 구분한다. 전체 표본을 가입자의 연령그룹별로 동일한 계좌수가 나누어지도록 5 개 그룹으로 분류하고, 각 그룹의 평균 위험선호도를 산출한 것이다. 저연령인 G1의 평균연령은 29.38세, 고연령인 G5는 55.00세이며, 그룹 간 5 8세 정도의 차이를 보인다.

\section{〈표 5〉연령그룹별 위험선호도}

이 표는 가입자의 연령그룹별 위험선호(평균값)를 보여주고 있다. 연령그룹은 전체 표본을 그룹별로 동일한 계좌수가 나누어지도록 5 개 그룹으로 분류하였다. 위험선호는 변동성(\%), 주식비중(\%), 원리금보장 상품비중(\%)으로, 변동성은 각 계좌의 펀드유형별 자산배분 비중에 동일유형의 과거 5 년간 공모펀드의 표준편차를 곱하여 계산하였으며, 주식비중은 펀드유형별 자산배분 비중에 유형별 평균 주식투자비중을 곱하여 계산한다. 그룹별 차이는 t-test를 수행하였으며, 괄호 안의 값은 $\mathrm{t}$-value를 나타내며, 옆의 ***, ** * 표시는 각각 유의수준 $1 \%, 5 \%, 10 \%$ 에서 통계적으로 유의미함을 나타낸다.

\begin{tabular}{lcccc}
\hline \multicolumn{1}{c}{ 연령그룹 } & 연령 & 변동성 & 주식비중 & 원리금보장비중 \\
\hline G1(저연령) & 29.38 & 1.13 & 11.98 & 45.99 \\
G2 & 35.52 & 1.46 & 15.87 & 38.08 \\
G3 & 41.02 & 1.57 & 17.23 & 35.18 \\
G4 & 46.97 & 1.71 & 19.07 & 33.21 \\
G5(고연령) & 55.00 & 1.54 & 17.02 & 37.13 \\
G5-G1 & & 0.42 & 5.04 & -8.86 \\
& & $(13.25)^{* * *}$ & $(14.31)^{* * *}$ & $(-8.90)^{* * *}$ \\
G5-G4 & -0.16 & -2.05 & 3.92 \\
& & $(-4.94)^{* *}$ & $(-5.52)^{* * *}$ & $(4.13)^{* * *}$ \\
G4-G1 & 0.58 & 7.09 & -12.78 \\
& & $(17.94)^{* * *}$ & $(19.60)^{* * *}$ & $(-13.05)^{* * *}$ \\
\hline
\end{tabular}

먼저 가장 고연령인 G5를 제외하면 연령이 증가할수록 위험선호도가 증가하는 패턴을 보인다. 변동성과 주식비중은 증가하는 반면, 원리금보장상품비중은 감소하는 추세를 보인다. 평균 연령이 
Investors' Risk Preference and Age in Korean Defined Contribution Plans

46.97세 정도인 G4그룹의 경우 평균적인 변동성은 $1.71 \%$, 주식비중은 $19.07 \%$, 원리금보장상품 비중은 $33.21 \%$ 로 가장 높은 위험선호도를 보인다. 반면, 저연령인 G1은 평균적인 변동성은 $1.13 \%$, 주식비중은 $11.98 \%$, 원리금보장상품비중은 $45.99 \%$ 로 가장 낮은 위험선호도를 보인다. 두 그룹 간의 차이(G4-G1)는 t-test 분석 결과 $1 \%$ 수준에서 유의미한 통계적 차이를 보인다. 이러한 결과는 앞서 모형 설계 시 가정했던 것과 같이 연령이 증가함에 따라 위험선호도가 증가할 것이라는 기대에 부응하는 것이라 하겠다.

하지만 가장 고연령인 G5에서는 다시 위험선호도가 감소하는 것으로 나타난다. G5그룹의 경우 평균적인 변동성은 $1.54 \%$, 주식비중은 $17.02 \%$, 원리금보장상품비중은 $37.13 \%$ 로 G4그룹 대비 위험선호도가 감소하며, 이러한 차이(G5-G4)는 t-test 분석 결과 $1 \%$ 수준에서 유의미한 통계적 차이이다. 즉, G4그룹에서 위험선호도가 최대가 되는 비선형적인 관계를 의미하며, 향후 회귀모형 적용 시 선형회귀모형 외 비선형모형에 대한 적합도도 분석해 볼 필요가 있다.

\subsection{2 연령그룹 내 가입자특성에 따른 위험선호도}

앞서 우리는 퇴직연금 가입자의 연령이 높을수록 위험선호도가 증가하는 패턴을 확인하였다. 이번에는 가입자의 연령과 위험선호도 사이의 관계에 영향을 미칠 수 있는 요인으로서 성별, 종사형태, 추가납입여부, 중도인출, 급여수준 및 누적적립금수준이 미치는 영향을 살펴본다. <표 6>은 가입자의 연령그룹별로 가입자특성에 따른 위험선호도를 산출한 결과이다. 위험선호도 지표로는 변동성, 주식비중, 원리금보장상품비중이 있으나, 주식비중과 원리금보장상품의 경우 혼합형(주식, 채권) 및 채권형을 통한 위험량을 계산하는데 한계가 있다. 반면, 변동성은 모든 상품유형의 위험도를 반영한 지표이기 때문에 <표 6>에서는 그룹별 변동성으로 분석을 수행한다. <표 5>와 마찬가지로 <표 6>에서도 연령그룹은 전체 표본을 가입자의 연령그룹별로 동일한 계좌수가 나누어지도록 5개 그룹으로 분류한다. Panel A는 이항변수로 정리가 되는 성별, 종사형태, 추가납입, 중도인출별로 연령그룹별 위험선호도(변동성)을 계산한 것이다. 추가납입과 중도인출은 금액에 무관하게 추가납입 및 중도인출이 있었는지 여부로 그룹을 나누었다. Panel $\mathrm{B}$ 는 전체 표본을 가입자의 급여 그룹별로 동일한 계좌수가 나누어지도록 5 개 그룹으로 분류한 것이며, Panel $\mathrm{C}$ 는 전체 표본을 가입자의 누적적립금 그룹별로 동일한 계좌수가 나누어지도록 5 개 그룹으로 분류한 것이다.

먼저 성별의 경우, 남성계좌의 전체 평균 변동성은 $1.55 \%$ 인 반면, 여성계좌는 $1.27 \%$ 로 $0.28 \% \mathrm{p}$ 차이가 난다. 전체 평균뿐만 아니라 모든 연령그룹별로도 남성계좌가 여성계좌 대비 상대적으로 높은 변동성을 보인다. 이는 앞서 예측한 바와 같이 남성이 상대적으로 여성 대비 위험선호도가 높음을 보여주는 결과라 하겠다. 다만, 남성의 경우, 전체표본과 동일하게 G4그룹에서 가장 높은 위험선호도를 보이고, 그룹별 차이도 명확하게 나타나는 반면, 여성의 경우 그보다 낮은 G3에서 가장 높은 위험선호도를 보이지만 G3에서 G4까지 변동성의 차이가 뚜렷하지 않다. 이는 상대적으로 남성의 경우 연령과 위험선호도 사이에 상관관계가 더 명확하게 나타날 가능성이 있음을 의미한다. 종사형태도 앞서 예상한 바와 같이 위험선호도가 높을 것으로 예상되는 임원의 평균적인 변동성이 $1.55 \%$ 로 높게 나타나며, 그룹 간 차이도 명확하게 나타난다. 추가납입여부로 구분한 경우, 추가납입 했을 때, 평균적인 변동성이 $2.04 \%$ 수준으로 높게 나타나며, 가장 높은 
한국증권학회지 제48권 6호 (2019)

연령그룹에서는 $2.29 \%$ 를 보일 정도로 높다. 따라서 추가납입여부도 추가납입 시 연령과 투자성과 사이에 상관관계가 더 명확하게 나타날 가능성이 있음을 의미한다. 이상의 결과는 모형설계 시 예측한 바와 같이 남성인 경우, 임원인 경우, 추가납입을 한 경우 위험선호도가 높을 것이라는 기대에 부응하는 결과이다. 하지만 중도인출여부의 경우, 실제 중도인출을 한 경우 위험선호도가

\section{〈표 6〉연령그룹 내 가입자특성에 따른 위험선호도(변동성)}

이 표는 연령그룹 내에서 가입자특성변수에 따른 위험선호도(변동성(\%))를 보여준다. 연령그룹은 전체 표본을 그룹별로 동일한 계좌수가 나누어지도록 5 개 그룹으로 분류하며, 변동성은 각 계좌의 펀드유형별 자산배분 비중에 동일유형의 과거 5년간 공모펀드의 표준편차를 곱하여 계산한다. Panel A는 성별과 종사형태, 추가납입, 중도인출에 따른 변동성을 계산한 것으로 성별은 남성계좌와 여성계좌로 구분하며, 종사형태는 근로자계좌와 임원계좌로 나누었다. 추가납입과 중도인출은 금액에 상관없이 여부로 구분하여 그룹별 변동성을 산출한 것이다. Panel $\mathrm{B}$ 는 급여수준 그룹별로 동일한 계좌수가 나누어지도록 5 개 그룹으로 분류하여, 그룹별 변동성을 산출한 것이며, Panel $\mathrm{C}$ 는 누적적립금수준 그룹별로 동일한 계좌수가 나누어지도록 5 개 그룹으로 분류하여, 그룹별 변동성을 산출한 것이다.

Panel A: 성별 및 종사형태

\begin{tabular}{|c|c|c|c|c|c|c|c|c|}
\hline \multirow{2}{*}{ 연령그룹 } & \multicolumn{2}{|c|}{ 성별 } & \multicolumn{2}{|c|}{ 종사형태 } & \multicolumn{2}{|c|}{ 추가납입 } & \multicolumn{2}{|c|}{ 중도인출 } \\
\hline & 남성 & 여성 & 근로자 & 임원 & 납입 & 미납입 & 인출 & 미인출 \\
\hline G1(저연령) & 1.22 & 1.02 & 1.02 & 1.22 & 1.61 & 1.12 & 1.23 & 1.12 \\
\hline G2 & 1.48 & 1.42 & 1.42 & 1.48 & 1.89 & 1.45 & 1.56 & 1.45 \\
\hline G3 & 1.59 & 1.50 & 1.50 & 1.59 & 2.29 & 1.54 & 1.57 & 1.57 \\
\hline G4 & 1.74 & 1.48 & 1.48 & 1.74 & 2.09 & 1.69 & 1.72 & 1.70 \\
\hline G5(고연령) & 1.58 & 1.17 & 1.17 & 1.58 & 2.05 & 1.52 & 1.58 & 1.54 \\
\hline 평균 & 1.55 & 1.27 & 1.27 & 1.55 & 2.04 & 1.46 & 1.57 & 1.47 \\
\hline
\end{tabular}

Panel B: 급여

\begin{tabular}{lccccc}
\hline 연령그룹 & 1그룹(저급여) & 2그룹 & 3그룹 & 4그룹 & 5그룹(고급여) \\
\hline $\mathrm{G} 1$ (저연령) & 1.07 & 1.17 & 1.22 & 1.21 & 1.01 \\
$\mathrm{G} 2$ & 1.45 & 1.43 & 1.57 & 1.61 & 1.27 \\
$\mathrm{G} 3$ & 1.20 & 1.51 & 1.59 & 1.81 & 1.58 \\
$\mathrm{G} 4$ & 1.08 & 1.51 & 1.67 & 1.95 & 1.74 \\
$\mathrm{G} 5$ (고연령) & 0.86 & 1.32 & 1.50 & 1.73 & 1.66 \\
\hline 평균 & 1.16 & 1.38 & 1.53 & 1.76 & 1.57 \\
\hline
\end{tabular}

Panel C: 누적적립금

\begin{tabular}{lccccc}
\hline \multicolumn{1}{c}{ 연령그룹 } & $\begin{array}{c}\text { 1그룹 } \\
\text { (저적립금) }\end{array}$ & 2그룹 & 3그룹 & 4그룹 & $\begin{array}{c}\text { 5그룹 } \\
\text { (고적 립금) }\end{array}$ \\
\hline $\mathrm{G} 1$ (저연령) & 0.93 & 1.29 & 1.51 & 1.72 & 0.72 \\
$\mathrm{G} 2$ & 1.04 & 1.40 & 1.66 & 1.80 & 1.56 \\
$\mathrm{G} 3$ & 0.91 & 1.38 & 1.57 & 1.83 & 1.86 \\
$\mathrm{G} 4$ & 0.92 & 1.20 & 1.55 & 1.98 & 1.88 \\
$\mathrm{G} 5$ (고연령) & 0.63 & 1.07 & 1.03 & 1.89 & 1.65 \\
\hline 평균 & 0.93 & 1.31 & 1.53 & 1.89 & 1.74 \\
\hline
\end{tabular}


Investors' Risk Preference and Age in Korean Defined Contribution Plans

오히려 높게 나타난다. 중도인출의 경우 전체 평균 변동성은 $1.57 \%$ 로 그렇지 않은 경우 $1.47 \%$ 대비 높게 나타난다. 다만, 그룹별 증감추세를 보면 오히려 미인출이 더 뚜렷한 차이를 보인다. 즉, 중도인출 여부는 연령과 투자성과 사이에 상관관계를 명확히 하는 요소는 아닐 수 있다는 추론이 가능하다. 다만, 각 연령그룹의 관측치수가 다르기 때문에 회귀분석으로 보다 엄밀한 검증을 통해 결과를 도출할 필요가 있다.

Panel B는 연령과 급여 그룹별로 위험선호도를 계산한 것으로 저급여 그룹(1그룹)의 평균적인 변동성은 $1.16 \%$ 인 반면, 고급여 그룹(5그룹)의 변동성은 $1.57 \%$ 이다. 급여가 높아짐에 따라 변동성이 증가하는 추세를 보인다. 연령그룹까지 고려한 경우, 연령그룹 G4의 급여그룹 4그룹에서 가장 높은 변동성인 $1.95 \%$ 를 보인다. 즉, 가장 높은 연령과 높은 급여에서는 추세가 역전되지만, 대체적으로 연령이 증가하고, 급여가 높아질수록 위험선호도(변동성)가 높아지는 추세를 보인다. Panel C는 연령과 누적적립금 그룹별로 위험선호도를 계산한 것으로 저적립금(1그룹)의 평균적인 변동성은 $0.93 \%$ 인 반면, 고적립금 그룹(5그룹)의 변동성은 $1.74 \%$ 이다. Panel B와 마찬가지로 연령그룹 G4의 적립금그룹 4그룹에서 가장 높은 변동성인 $1.98 \%$ 를 보이며, 대체 적으로 연령이 증가하고, 적립금이 많아질수록 위험선호도(변동성)가 높아지는 추세를 보인다. 즉, 상대적으로 급여와 적립금 수준이 높을수록 연령과 위험선호도 사이에 상관관계가 더 명확하게 나타날 가능성이 있음을 의미한다. 하지만 이 또한 25 개 그룹별 관측치수가 다르기 때문에 회귀분석으로 보다 엄밀한 검증을 통해 결과를 도출할 필요가 있다.

\section{2 회귀분석}

\subsection{1 연령과 위험선호 사이의 관계}

$<$ 표 7>은 본 연구의 회귀모형을 횡단면회귀분석으로 추정한 결과를 제시하고 있다.5) 앞서 연령과 위험선호도 사이에 비선형적인 관계가 있을 수 있음이 밝혀졌기 때문에, 최초 연구모형에서 제시한 회귀모형에 연령의 제곱항을 추가한 이차회귀모형을 추가분석 하였다. 먼저, 선형회귀 모형을 적용한 (1-1), (2-1), (3-1)의 경우, 주요 설명변수인 연령이 위험선호도와 유의수준 $1 \%$ 에서 통계적으로 유의한 관계를 보인다. 변동성과 주식비중의 경우, 통계적으로 유의한 음(-)의 회귀계수를 보이며, 원리금보장상품비중은 통계적으로 유의한 양(+)의 회귀계수를 보인다. 이러한 결과는 연령이 증가함에 따라 위험이 감소한다는 것을 의미한다. 이는 앞서 예상한 바와 반대되는 결과이다. <표 5>와 <표 6>에서 연령이 증가함에 따라 위험선호가 대체적으로 증가하는 모습을 보였다. 다만, 가장 고연령인 G5에서 위험선호가 감소하였다. 본 회귀분석에서는 $\mathrm{G} 5$ 의 영향에 따라 전체적인 회귀결과가 예상과 반대로 나온 것으로 판단된다. 이에 앞 절에서도 언급한 바와 같이 비선형적인 관계를 고려하여 회귀분석을 수행하는 것이 적절한 것으로 판단된다.

이차항을 적용한 (1-2), (2-2), (3-2)의 경우, 연령과 연령제곱항이 모두 위험선호도와 유의수준 $1 \%$ 에서 통계적으로 유의한 관계를 보인다. 변동성과 주식비중의 경우, 연령제곱항이 통계적으로 유의미한 음(-)의 회귀계수로 연령과 변동성 및 주식비중 간에 위로 볼록한 형태의 비선형함수로

5) 이분산성(heteroscedasticity)을 고려하여 회귀분석(white-corrected standard error model)을 수행 하여도 동일한 결과가 도출된다.

\section{8}


한국증권학회지 제48권 6호 (2019)

설명됨을 보인다. 반면, 원리금보장상품의 경우, 연령제곱항이 통계적으로 유의미한 양(+)의 회귀계수로 아래로 볼록한 비선형함수로 설명됨을 보인다. 또한 세 가지 위험선호지표 모두 연령제곱항을 추가하였을 때, 설명력이 높아진다. 이러한 결과는 <표 5>에서도 밝힌 바와 같이, 연령이 증가함에 따라 지속적으로 위험선호도가 증가하는 것이 아닌 위험선호도를 최대로 하는 구간이 있음을 의미한다. 이는 연령이 증가함에 따라 학습효과와 금융이해력이 높아지면서 위험선호도가 높아지지만, 은퇴가 가까워짐에 따라 은퇴자금을 확정하고자 하는 니즈가 반영된 것이라 해석할 수 있다. 특히, 위험부담(risk-taking)은 장기적으로 운용성과 개선을 이끌지만, 단기적으로는 변동성 확대의 부담이 있다는 점을 고려했을 때 합리적인 의사결정이라 판단된다.

\section{〈표 7〉 연령과 위험선호 사이의 관계}

이 표는 횡단면회귀분석을 통하여 퇴직연금 가입자의 연령이 위험선호에 미치는 영향을 분석한 결과이다. 종속변수는 변동성, 주식비중, 원리금보장상품비중으로, 변동성은 각 계좌의 펀드유형별 자산배분 비중에 동일유형의 과거 5 년간 공모펀드의 표준편차를 곱하여 계산하였으며, 주식비중은 펀드유형별 자산배분 비중에 유형별 평균 주식투자비중을 곱하여 계산한다. 본 연구의 주요 설명변수로서 가입자의 연령을 사용한다. 그리고 통제변수로는 성별더미(남성 $=1$, 여성 $=0)$, 임원더미(근로자 $=0$, 임원 $=1$ ), 가입기간(연), 급여(천 원), 누적적립금(천 원), 추가납입(천 원), 중도인출(천 원), 사업장의 종사자 수이다. 이 중 급여, 누적적립금, 추가납입, 중도인출은 $\ln$ 를 취하여 모형에 적용한다. 괄호 안의 값은 $\mathrm{t}-\mathrm{value}$ 를 나타내며, 옆의 *** *** * 표시는 각각 유의수준 $1 \%, 5 \%, 10 \%$ 에서 통계적으로 유의미함을 나타낸다.

\begin{tabular}{|c|c|c|c|c|c|c|}
\hline & \multicolumn{2}{|c|}{ 변동성 } & \multicolumn{2}{|c|}{ 주식비중 } & \multicolumn{2}{|c|}{ 원리금보장상품비중 } \\
\hline & $(1-1)$ & $(1-2)$ & $(2-1)$ & $(2-2)$ & $(3-1)$ & $(3-2)$ \\
\hline 연령 & $\begin{array}{l}-0.0180^{* * *} \\
(-12.37)\end{array}$ & $\begin{array}{c}0.0694^{* * *} \\
(6.93)\end{array}$ & $\begin{array}{l}-0.2031^{\text {*** }} \\
(-12.46)\end{array}$ & $\begin{array}{c}0.8220^{* * *} \\
(7.34)\end{array}$ & $\begin{array}{l}0.5475^{* * *} \\
(12.50)\end{array}$ & $\begin{array}{c}-1.7385^{* * * *} \\
(-5.78)\end{array}$ \\
\hline 연령 ${ }^{2}$ & & $\begin{array}{l}-0.0010^{* * *} \\
(-8.82)\end{array}$ & & $\begin{array}{c}-0.0119^{* * *} \\
(-9.25)\end{array}$ & & $\begin{array}{c}0.0264^{* * *} \\
(7.68)\end{array}$ \\
\hline 성별더미 & $\begin{array}{c}0.1840^{* * *} \\
(7.68)\end{array}$ & $\begin{array}{c}0.1613^{* * *} \\
(6.70)\end{array}$ & $\begin{array}{c}2.0080^{* * *} \\
(7.49)\end{array}$ & $\begin{array}{c}1.7417^{\text {**** }} \\
(6.48)\end{array}$ & $\begin{array}{c}-5.1313^{\text {*** }} \\
(-7.13)\end{array}$ & $\begin{array}{c}-4.5374^{* * *} \\
(-6.28)\end{array}$ \\
\hline 임원더미 & $\begin{array}{r}-0.0145 \\
(-0.16)\end{array}$ & $\begin{array}{r}0.0433 \\
(0.49)\end{array}$ & $\begin{array}{r}-0.2941 \\
(-0.30)\end{array}$ & $\begin{array}{r}0.3835 \\
(0.39)\end{array}$ & $\begin{array}{r}-0.2124 \\
(-0.08)\end{array}$ & $\begin{array}{r}-1.7234 \\
(-0.65)\end{array}$ \\
\hline 가입기간 & $\begin{array}{l}0.1112^{* * *} \\
(25.91)\end{array}$ & $\begin{array}{l}0.1094^{* * *} \\
(25.50)\end{array}$ & $\begin{array}{l}1.2964^{* * *} \\
(27.01)\end{array}$ & $\begin{array}{l}1.2746^{\text {*** }} \\
(26.58)\end{array}$ & $\begin{array}{l}-4.6389^{* * *} \\
(-35.98)\end{array}$ & $\begin{array}{l}-4.5902^{\text {*** }} \\
(-35.62)\end{array}$ \\
\hline $\ln$ (급여) & $\begin{array}{c}0.0893^{* * *} \\
(3.78)\end{array}$ & $\begin{array}{c}0.0805^{* * *} \\
(3.42)\end{array}$ & $\begin{array}{c}1.0383^{* * *} \\
(3.94)\end{array}$ & $\begin{array}{c}0.9358^{* * *} \\
(3.55)\end{array}$ & $\begin{array}{l}-8.3809^{* * *} \\
(-11.83)\end{array}$ & $\begin{array}{l}-8.1523^{\text {*** }} \\
(-11.51)\end{array}$ \\
\hline $\ln$ (적립금) & $\begin{array}{l}0.1675^{\text {*** }} \\
(10.30)\end{array}$ & $\begin{array}{c}0.1471^{* * *} \\
(8.98)\end{array}$ & $\begin{array}{l}2.0030^{* * *} \\
(11.02)\end{array}$ & $\begin{array}{c}1.7641^{\text {*** }} \\
(9.63)\end{array}$ & $\begin{array}{c}2.2182^{* * * *} \\
(4.54)\end{array}$ & $\begin{array}{c}2.7511^{\text {*** }} \\
(5.59)\end{array}$ \\
\hline $\ln$ (추가납입) & $\begin{array}{c}0.0316^{* * *} \\
(4.68)\end{array}$ & $\begin{array}{l}0.0324^{* * *} \\
(4.81)\end{array}$ & $\begin{array}{c}0.2926^{\text {*** }} \\
(3.88)\end{array}$ & $\begin{array}{c}0.3014^{\text {*** }} \\
(4.00)\end{array}$ & $\begin{array}{c}-0.9932^{* * *} \\
(-4.90)\end{array}$ & $\begin{array}{c}-1.0129^{* * *} \\
(-5.01)\end{array}$ \\
\hline ln(중도인출) & $\begin{array}{r}0.0057 \\
(1.34)\end{array}$ & $\begin{array}{r}0.0013 \\
(0.31)\end{array}$ & $\begin{array}{c}0.1322^{* * *} \\
(2.77)\end{array}$ & $\begin{array}{c}0.0804^{*} \\
(1.68)\end{array}$ & $\begin{array}{c}-0.4480^{* * *} \\
(-3.50)\end{array}$ & $\begin{array}{c}-0.3324^{\text {*** }} \\
(-2.58)\end{array}$ \\
\hline 종사자수 & $\begin{array}{c}-0.0073^{* * *} \\
(-3.59)\end{array}$ & $\begin{array}{c}-0.0045^{* *} \\
(-2.20)\end{array}$ & $\begin{array}{c}-0.0719^{* * *} \\
(-3.18)\end{array}$ & $\begin{array}{c}-0.0397^{*} \\
(-1.74) \\
\end{array}$ & $\begin{array}{r}-0.0548 \\
(-0.90) \\
\end{array}$ & $\begin{array}{c}-0.1268^{* *} \\
(-2.07)\end{array}$ \\
\hline adj $R^{2}$ & 0.0955 & 0.0991 & 0.1040 & 0.1080 & 0.0979 & 0.1007 \\
\hline 표본수 & 18,781 & 18,781 & 18,781 & 18,781 & 18,781 & 18,781 \\
\hline
\end{tabular}


Investors' Risk Preference and Age in Korean Defined Contribution Plans

통제변수들과 위험선호도 사이의 관계는 사전에 예상한 바와 크게 다르지 않은 결과를 보여주고 있다. 임원더미를 제외하면 모든 모형에서 통제변수들의 회귀계수는 유의수준 $1 \%$ 에서 유의미한 것으로 나타났다. 앞서 비선형회귀모형의 적합도가 높게 나타났기 때문에, (1-2), (2-2), (3-2) 중심으로 설명을 하면, 성별, 가입기간, 급여, 추가납입은 위험선호도와 양 $(+)$ 의 상관관계를 보인다. 즉, 변동성과 주식비중과는 통계적으로 유의미한 양 $(+)$ 의 상관관계를 보이는 반면, 원리금보장상품비중과는 통계적으로 유의미한 음 $(-)$ 의 상관관계를 보인다. 남성인 경우 여성보다 변동성은 $0.16 \% \mathrm{p}$, 주식비중은 $1.74 \% \mathrm{p}$ 높게 운용되는 반면, 원리금보장상품비중은 $4.54 \% \mathrm{p}$ 낮게 보유한다. 가입기간과 급여 또한 위험선호도와 양 $(+)$ 의 관계를 보여주고 있다. 가입기간은 1 년 증가함에 따라 변동성은 $0.11 \% \mathrm{p}$, 주식비중은 $1.27 \% \mathrm{p}$ 높게 운용되는 반면, 원리금보장상품비중은 $4.59 \% \mathrm{p}$ 낮게 보유한다. 급여는 2.72 배6) 증가함에 따라 변동성은 $0.08 \% \mathrm{p}$, 주식비중은 $0.94 \% \mathrm{p}$ 높게 운용되는 반면, 원리금보장상품비중은 $8.15 \% \mathrm{p}$ 낮게 보유한다. 마찬가지로 추가납입은 2.72 배 증가함에 따라 변동성은 $0.03 \% \mathrm{p}$, 주식비중은 $0.30 \% \mathrm{p}$ 높게 운용되는 반면, 원리금보장상품 비중은 $1.01 \% \mathrm{p}$ 낮게 보유한다. 급여와 추가납입의 경우, 변수의 변화에 따른 종속변수의 변화가 크다고 보긴 어려우나, 성별, 근속연수는 <표 $3>$ 에서 제시한 전체표본의 주식비중과 원리금 보장상품비중 평균이 각각 $16.24 \%$ 와 $37.92 \%$ 인 점을 고려한다면, 경제적으로 의미가 큰 수치라 할 수 있다.

반면, 누적적립금의 경우, 변동성과 주식비중, 원리금보장상품비중 모두에서 $1 \%$ 수준에서 통계적으로 유의미한 양(+)의 상관관계를 보인다. 변동성과 주식비중의 증가는 위험선호도 증가로 보이나, 원리금보장상품비중 또한 증가하기 때문에 단순히 위험선호도와 양(+)의 관계가 존재한다고 해석하기엔 한계가 있다. 적립금 규모를 가입자의 자산규모의 대용치로 본다면 다음과 같은 해석이 가능하다. 일반적으로 부유층일수록 투자정보 획득에 보다 많은 노력을 기울이고, 교육수준 및 금융이해력이 높기 때문에 위험선호도가 높아진다고 볼 수 있다. 하지만 반대로는 투자금액이 커짐에 따라 손실위험도 커지게 되어 안정적인 운용에 대한 니즈가 생긴다. 특히, 자금의 성격이 노후의 생계를 위한 자금이라면 변동성 회피 성향은 더욱 명확하게 나타날 것이다. 이러한 두 가지 효과로 인해, 적립금 규모가 증가함에 따라 변동성과 주식비중이 증가하지만, 한편으로는 원리금보장상품의 비중도 증가하는 상반된 결과가 도출된 것으로 유추된다.

중도인출은 주식비중과 통계적으로 유의미한 양(+)의 상관관계를 보이는 반면, 원리금보장상품 비중과는 통계적으로 유의미한 음(-)의 상관관계를 보인다. 이를 포괄해 해석하면, 중도인출 금액이 커짐에 따라 위험선호도가 증가한다고 해석이 가능하다. 앞서 중도인출은 퇴직연금을 제외한 자산이 부족함을 의미하며, 현재 삶을 위해 일정부분 노후소득을 포기한 것이기 때문에, 위험선호도와 음(-)의 관계를 보일 것이라는 예상과 반대되는 것이다. 하지만 단순히 중도 인출이라는 행위가 위험선호도에 따른 결과물이라기보다는 중도인출을 하는 상품유형이 금액이

6) 급여변수에 $\ln$ 을 취한 값을 회귀모형에 반영하였기 때문에, $\ln$ (급여) 변수의 1 단위 변화는 실제급여의 $\mathrm{e}($ 약 2.72) 변화를 의미한다. 
한국증권학회지 제48권 6호 (2019)

확정되어 있는 원리금보장상품에 치우친 결과라고 해석할 수도 있다. 원리금보장상품의 비중은 감소하고 주식비중은 증가하였으나, 모든 상품유형의 위험도를 종합적으로 반영한 변동성이 변하지 않았다는 것이 반증이라 하겠다. 마지막으로 사업장의 종사자 수는 모든 종속변수에 대해서 통계적으로 유의미한 음(-)의 상관관계를 가진다. 앞서 사업장의 종사자 수는 위험 선호도와 양 $(+)$ 의 상관관계를 가질 것으로 예상되었으나, 본 결과는 위험선호도와는 무관함을 보인다고 하겠다. 사업장의 크기가 커짐에 따라 위험선호도가 커진다기보다는 위험과 안정의 양 극단에 치우치지 않는 중위험-중수익 중심의 자산배분이 이루어지고 있음을 보여준다고 하겠다.

\subsection{2 가입자특성을 감안한 연령과 위험선호 사이의 관계}

앞서 퇴직연금 가입자의 연령과 위험선호도 사이에 양( $(+)$ 의 상관관계가 존재함을 확인하였다. 이에 추가적으로 가입자의 특성을 나타내는 6 개 요인에 대해 교차항을 포함한 회귀분석을 시행한다. 이를 통해 연령과 위험선호도 사이의 관계가 성별, 임원여부, 급여수준, 적립금수준, 추가납입여부, 중도인출여부에 따라 다른가를 검증한다. 급여수준은 급여금액이 상위 $50 \%$ 이상인 경우 1 의 값을 부여하고 그 외 0 의 값을 부여한 더미변수이며, 적립금수준은 누적적립금이 상위 $50 \%$ 이상인 경우 1 의 값을 부여하고 그 외 0 의 값을 부여한 더미변수이다. 추가납입여부는 납입금액에 상관없이 추가납입이 있으면 1 , 그렇지 않으면 0 을 부여한 더미변수이며, 중도인출은 중도인출이 있으면 1 , 그렇지 않으면 0 을 부여한 더미변수이다. 그리고 통제변수로는 기존 회귀모형과 동일하게 성별더미(남성 $=1$, 여성=0), 임원더미(임원 = 1 , 근로자 $=0$ ), 가입기간(연), 급여(천 원), 누적적립금(천 원), 추가납입(천 원), 중도인출(천 원), 사업장의 종사자 수이다. 이 중 급여, 누적적립금, 추가납입, 중도인출은 $\ln$ 를 취하여 모형에 적용한다. 앞서 연령의 제곱항을 포함한 비선형회귀모형의 설명력이 더 높게 나타났기 때문에, 본 분석에서도 연령의 제곱항을 포함한 비선형회귀모형을 적용한다.

<표 8>은 가입자특성을 감안한 연령과 위험선호 사이의 관계를 검증하기 위한 회귀모형을 횡단면회귀분석으로 추정한 결과이다. 먼저, 주요 설명변수인 연령과 연령제곱항은 모든 모형에서 <표 7>의 결과와 마찬가지로 위험선호도와 유의수준 $1 \%$ 에서 통계적으로 유의한 관계를 보인다. 변동성과 주식비중의 경우, 연령제곱항이 통계적으로 유의미한 음(-)의 회귀계수를 보이며, 연령과 변동성 및 주식비중 간에 위로 볼록한 형태의 비선형함수로 설명됨을 보인다. 반면, 원리금보장상품의 경우, 연령제곱항이 통계적으로 유의미한 양(+)의 회귀계수를 보이며, 아래로 볼록한 비선형함수로 설명됨을 보인다.

교차항 중에서는 임원, 급여, 적립금, 중도인출과의 교차항이 위험선호와 통계적으로 유의미한 양 $(+)$ 의 관계를 보인다. 임원은 동일연령의 근로자 대비 변동성은 $0.03 \% \mathrm{p}$, 주식비중은 $0.40 \% \mathrm{p}$ 높게 운용하는 반면, 원리금보장상품비중은 $1.22 \% \mathrm{p}$ 낮게 운용한다. 근로자는 모든 연령대에 고르게 분포한 반면, 임원은 50 대 그룹에 집중적으로 분포하고 있기 때문에 연령을 통제하지 않은 기존 <표 $7>$ 에서는 유의성이 없었던 것으로 판단된다. 하지만 연령과 임원여부를 교차항으로 만들어 연령을 통제함에 따라 더욱 명확하게 임원의 위험선호도 분석이 가능하게 
Investors' Risk Preference and Age in Korean Defined Contribution Plans

되었으며, 이러한 결과는 앞서 임원의 위험선호도가 높을 것이라는 기대에 부응하는 것이다. 급여수준 또한 동일연령에서 급여수준이 상위 $50 \%$ 에 해당하는 가입자가 하위 $50 \%$ 에 가입자 대비 변동성은 $0.0035 \% \mathrm{p}$, 주식비중은 $0.04 \% \mathrm{p}$ 높게 운용하는 반면, 원리금보장상품비중은 $0.15 \% \mathrm{p}$ 낮게 운용한다. 적립금수준 또한 급여수준과 유사한 결과를 보인다. 동일연령에서 적립금수준이 상위 $50 \%$ 에 해당하는 가입자가 하위 $50 \%$ 에 가입자 대비 변동성은 $0.0054 \% \mathrm{p}$, 주식비중은 $0.06 \% \mathrm{p}$ 높게 운용하는 반면, 원리금보장상품비중은 $0.22 \% \mathrm{p}$ 낮게 운용한다. 즉, 임원, 급여, 적립금의 결과를 보면, 동일한 연령대에서 임원일수록, 소득과 자산수준이 높을수록 위험에 대한 회피도가 낮아진다는 것으로 서두에 기대했던 결과와 동일하게 나타난다. 다만, 중도인출여부는 기대와 반대로 동일연령에서도 중도인출을 하면 위험선호도가 높게 나타난다.

〈표 8〉가입자특성을 감안한 연령과 위험선호 사이의 관계

이 표는 횡단면회귀분석을 통하여 퇴직연금 가입자의 연령과 가입자특성이 위험선호에 미치는 영향을 분석한 결과이다. 종속변수는 변동성, 주식비중, 원리금보장상품비중으로, 변동성은 각 계좌의 펀드유형별 자산배분 비중에 동일유형의 과거 5년간 공모펀드의 표준편차를 곱하여 계산하였으며, 주식비중은 펀드유형별 자산배분 비중에 유형별 평균 주식투자비중을 곱하여 계산한다. 본 연구의 주요 설명변수로서 가입자의 연령을 사용하며, 추가적으로 연령과 성별더미, 임원더미, 급여더미, 적립금더미, 추가납입더미, 중도인출더미의 교차항을 추가하였다. 급여더미는 급여금액이 상위 $50 \%$ 이상인 경우 1 의 값을 부여하고 그 외 0 의 값을 부여한 것이며, 적립금더미는 누적적립금이 상위 $50 \%$ 이상인 경우 1 의 값을 부여하고 그 외 0 의 값을 부여한 것이다. 추가납입더미는 추가납입이 있으면 1 , 그렇지 않으면 0 을 부여하고, 중도인출은 중도인출이 있으면 1 , 그렇지 않으면 0 을 부여한 것이다. 그리고 통제변수로는 성별더미(남성 $=1$, 여성 = 0 ), 임원더미 (근로자 $=0$, 임원 $=1$ ), 가입기간(연), 급여(천 원), 누적적립금(천 원), 추가납입(천 원), 중도인출(천 원), 사업장의 종사자 수이다. 이 중 급여, 누적적립금, 추가납입, 중도인출은 $\ln$ 를 취하여 모형에 적용한다. 괄호 안의 값은 $\mathrm{t}-\mathrm{value}$ 를 나타내며, 옆의 ${ }^{* * *},{ }^{* *},{ }^{*}$ 표시는 각각 유의수준 $1 \%, 5 \%$, $10 \%$ 에서 통계적으로 유의미함을 나타낸다.

\begin{tabular}{|c|c|c|c|}
\hline & 변동성 & 주식비중 & 원리금보장상품비중 \\
\hline 연령 & $0.0776(7.58)^{* * *}$ & $0.9289(8.12)^{* * *}$ & $-2.1547(-7.02)^{* * *}$ \\
\hline 연령 ${ }^{2}$ & $-0.0011(-9.22)^{* * *}$ & $0.0137(-9.88)^{* * * *}$ & $0.0343(9.23)^{* * * *}$ \\
\hline 연령×성별더미 & $-0.0049(-1.73)^{*}$ & $-0.042(-1.33)$ & $0.015(0.19)$ \\
\hline 연령×임원더미 & $0.0345(2.39)^{* *}$ & $0.402(2.50)^{*}$ & $-1.224(-2.83)^{* *}$ \\
\hline 연령×급여더미 & $0.0035(4.64)^{* * * *}$ & $0.042(5.09)^{* *}$ & $-0.149(-6.73)^{* *}$ \\
\hline 연령×적립금더미 & $0.0054(6.70)^{* * *}$ & $0.064(7.13)^{* *}$ & $-0.216(-8.97)^{* *}$ \\
\hline 연령×추가납입더미 & $0.0095(1.43)$ & $0.127(1.71)$ & $-0.155(-0.78)$ \\
\hline 연령×중도인출더미 & $0.0192(3.28)^{* * * *}$ & $0.220(3.36)^{* *}$ & $-0.786(-4.47)^{* *}$ \\
\hline 성별더미 & $0.3403(3.04)^{* * *}$ & $3.243(2.59)^{* *}$ & $-4.744(-1.41)$ \\
\hline 임원더미 & $-1.7203(-2.29)^{* *}$ & $-20.205(-2.40)^{*}$ & $60.782(2.70)^{* *}$ \\
\hline 가입기간 & $0.1075(25.03)^{* * *}$ & $1.250(26.06)^{* *}$ & $-4.498(-34.93)^{* *}$ \\
\hline $\ln ($ 급여 $)$ & $-0.0090(-0.30)$ & $-0.169(-0.50)$ & $-4.142(-4.54)^{* *}$ \\
\hline $\ln$ (적립금) & $0.0712(3.58)^{* *}$ & $0.854(3.85)^{* *}$ & $5.871(9.86)^{* *}$ \\
\hline $\ln ($ 추가납입) & $-0.0214(-0.56)$ & $-0.418(-0.99)$ & $-0.115(-0.10)$ \\
\hline $\ln ($ 중도인출) & $-0.0742(-3.09)^{* *}$ & $-0.782(-2.92)^{* *}$ & $2.761(3.84)^{* *}$ \\
\hline 종사자수 & $-0.0058(-2.84)^{* *}$ & $-0.055(-2.44)^{* * *}$ & $-0.066(-1.09)$ \\
\hline $\operatorname{adj} R^{2}$ & 0.1034 & 0.1129 & 0.1087 \\
\hline 표본수 & 18,781 & 18,781 & 18,781 \\
\hline
\end{tabular}


한국증권학회지 제48권 6호 (2019)

이는 앞서 <표 $7>$ 에서도 밝힌 바와 같이 위험선호도가 반영된 결과라기보다는 중도인출을 하는 상품유형이 금액이 확정되어 있는 원리금보장상품에 치우친 결과라고 보는 것이 합리적일 것이다. 이 외 통제변수는 <표 $7>$ 과 회귀계수의 크기 차이는 있지만 방향성과 통계적 유의성에서 유사한 결과를 보인다.

\section{4. 결론}

본 연구에서는 우리나라의 확정기여형 퇴직연금제도 가입자에 대한 운용관리 정보와 퇴직연금 펀드 정보를 활용하여 가입자 연령이 위험선호에 미치는 영향을 분석하였다. 구체적으로 2017년 상반기 기준 확정기여형 퇴직연금제도를 운영 중인 350여 개 사업체 소속 근로자 1 만 8천여 명 대상으로 가입자의 연령과 위험선호(선택한 펀드의 변동성, 주식투자비중, 원리금보장상품 비중) 간 관계를 규명하였다.

회귀분석 결과, 확정기여형 가입자의 연령과 위험선호 사이에는 유의수준 $1 \%$ 에서 통계적으로 유의한 관계를 갖는다. 연령과 변동성, 주식투자비중의 경우, 연령에 대한 회귀계수는 양(+), 연령제곱에 대한 회귀계수는 음(-)으로 추정되어 위로 볼록한 비선형함수로 설명된다. 반면, 원리금보장상품의 경우, 연령에 대한 회귀계수는 음(-), 연령제곱항에 대한 회귀계수는 양(+)으로 추정되어 아래로 볼록한 비선형함수로 설명된다. 이러한 추정결과는 가입자의 연령이 증가함에 따라 위험선호도가 지속적으로 증가하는 것이 아니라 최적 구간 이후에는 위험선호도가 하락하는 것을 의미한다.

성, 가입기간, 급여 및 적립금 수준 등 통제변수들과 위험선호도 사이의 관계도 합리적인 예상과 부합되는 것으로 나타났다. 여성에 비해 남성의 위험선호도가 높고, 가입기간이 길고 급여수준이 높을수록 위험선호도도 높아진다. 또한 적립금의 규모가 클수록 위험선호도가 높아진다. 연령과 주요 변수에 대한 상호작용효과를 검증한 결과, 동일한 연령대에서 임원일수록, 소득과 자산수준이 높을수록 위험선호도가 높아지는 것으로 나타났다.

본 연구의 기여는 실증분석 대상이 된 확정기여형 가입자 범위를 크게 확대하여 연령이 위험선호에 미치는 영향을 검증하였다는 것이다. 확정기여형 가입자들은 자신의 계좌를 보유하고 위험자산에 대해 투자할 수 있기 때문에 퇴직연금사업자가 가입자 투자행태에 대해 이해한다면 더 경쟁력 있는 서비스를 제공할 수 있을 것이다. 향후에도 확정기여형 퇴직연금 가입자 수가 지속적으로 증가하고 적립금 규모도 늘어날 것이며, 위험자산에 대한 투자한도 규제는 더욱 완화될 여지가 있으므로 실제 가입자 계좌를 활용한 다양한 분석이 지속적으로 이루어져야 할 것이다.

본 연구는 확정기여형 퇴직연금 가입자의 실제 가입정보를 활용하여 연령과 위험자산 보유 간 관계를 확인하였다는데 의의가 있지만, 다음과 같은 한계점도 존재한다. 첫째, 특정시점(2017년 상반기) 자료로 횡단면 분석만 가능하다는 한계가 있다. 즉, 특정시점의 가입자 분포를 이용하였기 때문에 가입자 개개인의 연령변화에 따른 위험선호 변화를 확인하지는 못하였다. 둘째, 특정 퇴직연금사업자의 정보로 한정되었다는 점이다. 특히, 정보를 제공한 퇴직연금사업자의 경우 
Investors' Risk Preference and Age in Korean Defined Contribution Plans

전체 퇴직연금시장 대비 대형사업장의 비중이 높게 포함되어 있으며, 이는 개별 금융기관의 계좌정보를 사용하기 때문에 발생하는 한계이다. 따라서 이를 퇴직연금시장 전체로 일반화 하는데 주의가 필요하며, 향후 중·소규모 사업장의 퇴직연금 정보가 확보된다면 추가적인 연구가 필요하다. 셋째, 가입자가 선택한 상품(펀드)의 세부 정보가 부족하여 종속변수인 변동성과 주식비중 계산 시 공모펀드의 대용치를 사용하였다. 동일한 주식형 펀드라 하더라도 중소형 주식형과 배당주식형의 위험도는 상이하며, 동일한 주식혼합형 펀드여도 주식비중은 30 $60 \%$ 까지 다양하다. 따라서 가입자가 선택한 상품의 세부정보까지 확인하여 가입자별로 정확한 변동성과 주식비중을 도출하여 추가 연구가 이루어져야 한다. 이러한 한계점을 보완하여 후속 연구가 이루어져야 할 것이다. 


\section{References}

Agnew, J., P. Balduzzi, and A. Sunden, 2003, Portfolio Choice and Trading in a Large 401(k) Plan, The American Economic Review, Vol. 93, pp. 193-215.

Ameriks, J., and S. P. Zeldes, 2004, How Do Household Portfolio Shares Vary with Age?, Working Paper, Columbia University.

Bailey, W., A. Kumar, and D. T. Ng, 2011, Behavioral Biases of Mutual Fund Investors, Journal of Financial Economics, Vol. 102, pp. 1-27.

Bajtelsmit, V., and J. VanDerhei, 1997, Risk Aversion and Pension Investment Choices, in M. S. Gordon, O. S. Mitchell, and M. M. Twinney (Eds.), Positioning Pensions for the Twenty-First Century, The Pension Research Council, University of Pennsylvania.

Barber, B. M., and T. Odean, 2001, Boys will be Boys: Gender, Overconfidence, and Common Stock Investment, Quarterly Journal of Economics, Vol. 116, pp. 261-292.

Cardak, B., and R. Wilkins, 2009, The Determinants of Household Risky Asset Holdings: Australian Evidence on Background Risk and other Factors, Journal of Banking \& Finance, Vol. 33, pp. 850-860.

Choi, C., 2013, A Study on Financial Asset Allocation Behaviors of Korean Financial Consumers, Journal of Consumer Studies, Vol. 24 (1), pp. 297-325.

Joung, S. H., and M. K. Shin, 2011, A Study on the Related Variables to Financial Risk Tolerance and the Ratio of Risky Asset Possession, Financial Planning Review, Vol. 4 (4), pp. 1-20.

Kim, H. S., and K. H. Lee, 2013, An Analysis for the Behavior of Asset Allocation in a Defined Contribution Plan, Journal of Risk Management, Vol. 24 (2), pp. 3-39.

Lee, J. Y., and J. Y. Jung, 2011, Study on the Gender Differences of Financial Risk Tolerance, Family and Environment Research, Vol. 49 (10), pp. 1-13.

Lusardi, A., and O. S. Mitchell, 2011, Financial Literacy around the World: An Overview, Working Paper 17107, National Bureau of Economic Research.

Niebling, F., S. Meyer, and A. Hackethal, 2009, Whose Money is Smart? Mutual Fund Purchases of Private Investors, Working Paper, Social Science Research Network.

Statistics Korea, 2018, The First Half Year Retirement Pension Statistics for 2017, Press Release.

Song, I. W., Y. K. Park, S. Y. Lee, and Y. M. Choi, 2014, Age and Investment Performance: Evidence from Fund Investments, Korean Journal of Financial Studies, Vol. 43 (3), pp. 543-571.

Tang, N., O. S. Mitchell, G. R. Mottola, and S. Utkus, 2010, The Efficiency of Sponsor and Participant Portfolio Choices in 401(k) Plans, Journal of Public Economics, Vol. 94, pp. 1073-1085. 